\title{
Factors to Increase Tourist Loyalty in North Sumatera
}

\author{
Onan Marakali Siregar ${ }^{1}$, Selwendri $^{2}$, Maulidina ${ }^{3}$ \\ ${ }^{1,2}$ Business Administration, Universitas Sumatera Utara, Medan, Indonesia \\ ${ }^{3}$ Politeknik Lembaga Pendidikan dan Pengembangan Profesi Indonesia (LP3I), Medan, Indonesia \\ onanmsiregar@gmail.com
}

\begin{abstract}
North Sumatra Province is an area that has several attractions, both natural and cultural attractions. Some well-known tourist objects from abroad to foreign countries such as Lake Toba, and Mount Lawang with Sumateran orangutans. While is one of the gateways to reach tourist destinations in North Sumatra Province, including the city that has the Maimun City Palace and the Great Mosque that represents the history of the continuity of the Malay Kingdom, the Tjong A Fie House and the colonial colonial buildings that have talked about for years. This study aims to analyze and determine how to encourage tourists, destination images, and tourist satisfaction with tourist loyalty in North Sumatra Province. This research uses quantitative methods with data analysis methods. Multiple linear regression because it is based on two or more independent variables on variables, after that the data processing technique uses SPSS version 22 as a tool. This study found that the results consisted only of motivation variables which did not have a significant effect, while other variables had a significant effect on tourist loyalty. The results showed that the independent variables consisted of motivation variables (X1), destination image variables $(X 2)$, and satisfaction (X3) positively and significantly towards the variables supported by tourist loyalty $(Y)$ visiting the tourist area of North Sumatra Province. This study obtained results consisting of the majority of visitors consisting of students aged 17 to 25 years. Lake Toba, Bukit Lawang, and Berastagi are the dominant mainstay sectors, and the level of tourist visits to the Province of North Sumatra is still categorized as low.
\end{abstract}

Keywords

tourist loyalty, tourismdestinations, north Sumatera Province.

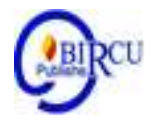

\section{Introduction}

North Sumatera Province is an area that has some interesting tourism objects, both natural and cultural tourism. Even some of the tourism objects have been widely known to foreign countries such as Lake Toba, which is located in Simalungun District, with a beautiful panorama of nature and in Langkat district there is also Bukit Lawang with a unique Sumateran orang utans, different from Borneo's orang utan. The city of Medan itself as one of the gates to various tourist destinations in Sumatra, has a number of city attractions such as Maimun Palace with Grand Mosque and Pond King, which is a witness of the continuity of the Kingdom of Sultan Melayu. Tjong A Fie with Kesawan area, and old building that has been hundreds of years. 
In the past, Medan was known as a trading city where there stood a number of plantation company headquarters such as Tobacco Deli and PT. London Sumatera, which are famous to foreign countries According to data from BPS, the number of foreign tourists who came to visit North Sumatra in December 2017 reached 27,978 visits, experienced a 11.95 percent increase compared with the coming in November 2017 reached 24,991 visits. Nevertheless, compared with the same month in 2016, the number of foreign tourists in December 2017 dropped 3.36 percent, from 28,950 visits in December 2016 to 27,978 visits. For the period of January to December 2017, the number of foreign visitors who came to visit North Sumatera increased by 12.02 percent compared to the same period in 2016, namely from 233,643 visits in the year 2016 to 261,736 visits in 2017.

Looking at the number of tourists who have increased in the year 2017, the tourism sector can be said to have great potential to be developed as one of the regional sources of income. Utilization of resources and tourism potential of the region is expected to contribute to economic development. Some of the tourist destinations above is a location that is already known by tourists, there are still some areas of tourism location again in North Sumatra. This can certainly increase the regional revenue in North Sumatera. But the head of the statistical (BPS) Syech Suhaimi said the visit of foreign tourists to North Sumatera period of JanuaryFebruary 2018 down compared to the same period 2017 is 32,925 people, while January February 2017, foreign tourists in North Sumatera amounting to 37,916 visits. The tourists enter from several entrances in North Sumatera, namely foreign tourists from Kualanamu Airport in the period from January to February 2018 as much as 32,437 from the same period 2017 that as many as 34,137 people. From the port Belawan also dropped to only 20 people from as many as 2,795 people in the same period 2017 while from Tanjung Balai Asahan lived 468 people from the same period 2017 that 984 visits.

Chairman of the Association of travel Companies or Asita North Sumatera, Solahuddin Nasution said, referring to the number of visitors visiting at the beginning of 2018, North Sumatera, it is very difficult to reach the target. One million foreign tourists visits. He also said the need for a more vigorous promotion and continued. Enhance and increase the number and quality of tourism objects in the various areas of North Sumatera. Moreover, Lake Toba that is being addressed by the Government today is not able to attract maximum visitors. This situation is very concern because North Sumatera has a geographical advantage is not able to increase foreign tourists visit. The efforts of North Sumatra province in promoting the region both overseas and to other provinces in Indonesia have often been done. This business has not been able to increase foreign tourists visit.

From the phenomenon, the decrease in the number of tourists North Sumatera, but the promotion has been conducted by the local government, then the author wants to examine about the motivation of traveling, the image of the tourist area that becomes a unique attraction for tourists and satisfaction Tourists who come to visit North Sumatera. If you can see how the Travellers views and satisfaction are perceived by tourists, this can affect the number of tourists visiting North Sumatera. The aim of the research done is to look at and look for factors that can increase the loyalty of tourists to visit back to tourist destinations in North Sumatera.

\section{Review of Literatures}

\subsection{Tourist Decisions in Regional Selection of Tourist Destinations}

According to Mill (2000), the attraction is one of the factors that greatly affects the tourists who come to a tourist destination area. The function is to meet the needs of tourists 
during their stay for a while in Tourist destinations visited. The facility is a factor that significantly affects consumers to be able to purchase the products offered. With the availability of means that will encourage potential tourists to visit and enjoy the tourist objects with a relatively long time, the accessibility is all that can provide tourists to come to visit in a destination area Tourism (DTW).

\subsection{Tourists Motivation to Travel}

Motivation is a key part of the travellers' behavioral process (Hsu, Cai, \& Li, 2009). Psychologically, motivation arises when a consumer wants to fulfill a need. Tensions are generated and arise from the need to create a consumer effort to meet that need. Crompton (in Nguyen, 2016) divides the motivation factor of the journey into two groups namely push factor and pull factor. He defines push factor/driving factor (also referred to as sosiopsychological) as a self-escape, self-exploration, relaxation, prestige, regression, increased kinship, and interaction Social.

On the other hand, pull factor also referred to as external motivation (Nguyen, 2016). Hsu, Cai, and Li (2009) adopted a model from gnoths, emphasizing the relationship between hope, motivation, and attitude (EMA's model), to explain the motivation of the journey. They argue that:

1. Hope tourists to visit the tourist destinations out of the country have a direct influence on their motivation to visit the destination.

2. The motivation of tourists has a direct effect on their attitude towards visits to the destination.

3. Travellers ' expectations for visiting an outbound destination have a direct effect on their attitude towards a visit to their destination.

4. Motivation has the effect of mediation on the relationship between hope and attitude.

\subsection{Tourist Destination Imagery}

The image of the destination area (perceived destination image) is a person's impression of a place, consisting of beliefs, ideas, and Prejudice Lawson \& Baud-Bovy (Nguyen, 2016). Imagery will help travellers consider whether the destination area matches their mental image and recreational demands. According to Ahmed (Nguyen, 2016) the concept of imagery evolved from organic imagery, through induced imagery, to more complex imagery. According to Gunn (Nguyen, 2016) the organic imagery deals with traveler's impressions of the destination without visiting the place.

\subsection{Quality of Tour Services}

According to Supranto (1997) quality is a word for service providers is something to be done well. The application of quality as the nature of product appearance or performance is a major part of the company's strategy in order to achieve sustainable excellence, either as a market leader or as a strategy to continue to grow.

The dimension of service quality developed by Parasuraman et.al (1988) identifies five dimensions of service quality, namely:

1. Physical evidence (tangible), which describes the physical facilities, equipment, and appearance of the personnel as well as the presence of users.

2. Reliability, which demonstrates the company's ability to provide service accurately and reliably, can be trusted, responsible for what it promises to never deliver an excessive promise and always meet Promise.

3. Responsiveness (responsiveness), which includes the desire to assist the customer in providing fast and precise service, always give the right and immediate attention, and about the customer. 
4. Assurance, which includes knowledge and politeness of workers and the ability of workers to provide services that give rise to the trust of the customers. This dimension reflects corporate competence, hospitality to customers and the security of its operations.

5. Empathy (empathy), which shows the degree of attention given to each customer. This dimension also reflects the ability of the worker to dive into the feelings of customers as if the worker itself experienced it.

\subsection{Overall Satisfaction of Tourism}

In particular, "tourism satisfaction" refers to the emotional state of travellers after exposure to opportunities or experiences (Baker and Crompton, 2000). When customers experience attributes of hospitality experience, they form a set of independent impressions on each one and compare them with the expectation of the same attributes (Pizam \& Ellis, 1999 in Nguyen 2016). Consumer Satisfaction Index (CSI) is very useful for corporate internal purposes. Examples of this are monitoring service improvements, employee's strikers and bonuses as a description representing customer's overall satisfaction level. CSI is used to thoroughly determine the level of visitor satisfaction by looking at the level of importance of product/service attributes.

CSI is an index to determine the level of customer satisfaction thoroughly with an approach that takes into consideration the level of importance of the measured attributes. The Consumer Satisfaction Index (CSI) is very useful for corporate internal purposes. Examples of this are monitoring service improvements, employee's strikers and bonuses as a description representing customer's overall satisfaction level.

To know the magnitude of CSI, you can do the following steps (Aritonang, 2005):

1. Determining the Mean Importance Score (IE) each variabel,

2. Create a Weight Factors (WF) per variable. This weight represents the percentage of MIS values per variable for the total MIS of all variables,

3. Determining the Mean Satisfaction Score (MSS) of each attribute,

4. Create the Weight Score (WSk) of each variable. This weight is a multiplication between WFk and MSSk, and

5. Determine Customer Satisfaction Index (CSI)

$$
\mathrm{CSI}=\frac{\sum_{\mathrm{k}-1}^{\mathrm{p}} \mathrm{wS}_{\mathrm{k}}}{\mathrm{HS}} \times 100 \%
$$

Where HS (Highest scale $)=$ the maximum scale used (Octaviani, 2006). 
Table 1. Customer Satisfaction Index Interpretation Number

\begin{tabular}{cc}
$X \leq 64 \%$ & Very poor \\
\hline $64 \%<X \leq 71 \%$ & Poor \\
\hline $71 \%<X \leq 77 \%$ & Cause for concern \\
\hline $77 \%<X \leq 80 \%$ & Borderline \\
\hline $80 \%<X \leq 84 \%$ & Good \\
\hline $84 \%<X \leq 87 \%$ & Very Good \\
\hline $87 \%<X$ & Excelent
\end{tabular}

\section{Research Method}

The research methods used are quantitative and causal research that aims to collect, analyze, classify, and map data about the prevailing conditions, practices, beliefs, processes, trends, and cause and effect relationships, Research will be done in four tourist sites of North Sumatra, namely Lake Toba, Bukit Lawang, Berastagi and the city of Medan. The population in this study is visiting tourists and traveling to these locations where the amount is not known for sure. In this study, formula of assessment interval as follows according Supramono and Haryanto (2003).

$$
\begin{gathered}
\mathrm{n}=\frac{(Z a)^{2}(p)(q)}{d^{2}} \\
\mathrm{n}=\frac{1,96^{2}(0,5)(0,5)}{(0,1)^{2}} \\
\mathrm{n}=96,04
\end{gathered}
$$

Description:

$\mathrm{N}$ : Number of samples

$\mathrm{Z} \alpha$ : The normal standard value of the amount depends $\alpha$

P: Estimator of population proportions

$\mathrm{q}: 1-\mathrm{p}$

D: tolerated irregularities

Based on the above calculations, the minimum number of samples in this study was 96.04. To facilitate the calculation and retrieval of samples, each region was taken a number of 30 samples, so that the total sample for 4 research areas became 120 samples.

Regression analyses are used to measure the strength of the relationship between two or more variables, and to indicate the direction of the relationship between the dependent variables and the independent variables. Multiple Linear regressions are based on the influence of two or more free variables against bonded variables. Here's a formula to see multiple analyses:

$$
\mathrm{Y}=\mathrm{a}+\mathrm{b} \_1 \mathrm{X} \_1+\mathrm{b} \_2 \mathrm{X} \_2+\mathrm{b} \_3 \mathrm{X} \_3+\mathrm{e}
$$

$$
\begin{array}{ll}
\mathrm{Y} & =\text { Tourist Loyalty } \\
\mathrm{X}_{1} & =\text { Tourist Motivation } \\
\mathrm{X}_{2} & =\text { Destination Imagery } \\
\mathrm{X}_{3} & =\text { Tourist Satisfaction } \\
\mathrm{a} & =\text { Constant }
\end{array}
$$




\section{Discussion}

\subsection{Multiple Linear Regression Analysis}

Multiple linear regression analyses are used in this study for the purpose of knowing whether there is an influence on independent variables of motivation (X1), Destination image (X2), and Satisfaction (X3) for the dependent variable of Travellers loyalty (Y).

Table 1. Multiple linear regression.

\begin{tabular}{|c|c|c|c|c|c|}
\hline \multirow[t]{2}{*}{ Model } & \multicolumn{2}{|c|}{$\begin{array}{c}\text { Unstandardized } \\
\text { Coefficients }\end{array}$} & $\begin{array}{l}\text { Standardized } \\
\text { Coefficients }\end{array}$ & \multirow[t]{2}{*}{$\mathrm{T}$} & \multirow[t]{2}{*}{ Reserves the } \\
\hline & B & Std. Error & Beta & & \\
\hline (Constant) & 2.315 & 1.105 & & 2.094 & .038 \\
\hline Motivation & -.019 & .053 & -.032 & -.363 & .717 \\
\hline Destination image & .260 & .058 & .413 & 4.506 & .000 \\
\hline Satisfaction & .155 & .040 & .353 & 3.907 & .000 \\
\hline
\end{tabular}

A. Dependent variables: Tourist loyalty

Source: Data Processing results (2019)

According to the Table 1, the results if written in the form of standardized of the equation regression is as follows:

$$
\begin{aligned}
& Y=\alpha+\beta_{1} X_{1}+\beta_{2} X_{2} \\
& Y=4,836+0.375 X 1+0.322 X 2
\end{aligned}
$$

The multiple regression equation is described as follows:

1. A positive constant () value of 2.315 , shows that positive effect is the free variable motivation, destination image, and satisfaction. When a variable is free to rise or influence in one unit, the travellers' loyalty variables will be increased or fulfilled. $\alpha$

2. The value of the coefficient of X1 (B1) of - $(0.019)$ indicates that the motivation variable negatively affects the travellers loyalty variables or in other words if the demotivated value of $1 \%$ will increase the travellers loyalty by 0.019 .

3. The coefficient value of X2 (B2) of 0.260 indicates that the destination image variable has a positive effect on a travellers loyalty variable or in other words if an increased destination image value of $1 \%$ will increase loyalty interest Travelers of 0.260 .

4. The coefficient value of X3 (B3) of 0.155 indicates that the satisfaction variable has a positive effect on travellers loyalty variables or in other words if the increased satisfaction value of $1 \%$ will increase the interest of the tourist loyalty of 0.155 .

\subsection{Hypothesis Testing}

a. Partial Test (Test T)

The decision making criteria is:

1. $\mathrm{H} 0$ is rejected if the count $\mathrm{T}$ value $<\mathrm{T}$ value of table or sig value $>0.05$ at $\alpha=5 \%$

2. Ha accepted if the value of $\mathrm{T}$ count $>\mathrm{t}$ Value of table or sig $<0.05$ at $\alpha=5 \%$

Error rate $(\alpha)=5 \%$ and degrees of freedom $(\mathrm{DF})=(\mathrm{n}-\mathrm{k})$

$\mathrm{n}=$ number of samples, $\mathrm{n}=120$

$\mathrm{k}=$ number of variables used, $\mathrm{k}=4$

Free degrees $(\mathrm{DF})=\mathrm{n}-\mathrm{k}=120-4=116$

So $t$ the table used is $\mathrm{t}(5 \%)(116)$ or $\mathrm{T} 0.05(116)=1.658$. 
Table 2. Partial test (Test T)

\begin{tabular}{|c|c|c|c|c|c|}
\hline \multirow{2}{*}{ Model } & \multicolumn{2}{|c|}{$\begin{array}{c}\text { Unstandardized } \\
\text { Coefficients }\end{array}$} & $\begin{array}{c}\text { Standardized } \\
\text { Coefficients }\end{array}$ & \multirow{2}{*}{ T } & \multirow{2}{*}{ Reserves the. } \\
\cline { 2 - 4 } & B & Std. Error & Beta & & \\
\hline 1 & 2.315 & 1.105 & & $\mathbf{2 . 0 9 4}$ & .038 \\
\hline (Constant) & -.019 & .053 & -.032 & $\mathbf{- . 3 6 3}$ & .717 \\
Motivation & .260 & .058 & .413 & $\mathbf{4 . 5 0 6}$ & .000 \\
Destination image & .155 & .040 & .353 & $\mathbf{3 . 9 0 7}$ & .000 \\
\hline Satisfaction & A & &
\end{tabular}

A. Dependent variables: Tourist loyalty

Source: Data Processing results (2019) follows:

Based on the table above can be seen the influence of each variable partially is as

1. Known to the significant value of the motivation variable is sig. of $0.717>0.05$ and the calculate value of $\mathrm{T}-(0.363)<\mathrm{T}_{\text {table }} 1.658$ then $\mathrm{H} 1$ is rejected.

2. Known to the significant value of the destination image variable that is sig. $0.000<0.05$ and the calculated $\mathrm{T}$ value of $4.506>\mathrm{t}_{\text {table }} 1.658$ then $\mathrm{H} 2$ Received.

3. Known to the significant value of satisfaction variables i.e. sig. $0.000<0.05$ and the calculated $_{\text {a }}$ $\mathrm{T}$ value of $3.907>\mathrm{t}_{\text {table }} 1.658$ then $\mathrm{H} 3$ is accepted.

4. In accordance with the existing theory it is apparent that the destination image variables and satisfaction have significant effect on the traveller's loyalty interests.

b. Simultaneous Test (F test)

The decision making criteria is:

1. $\mathrm{H} 0$ rejected if value $\mathrm{F}$ is calculated $\langle\mathrm{F}$ value of table or sig value $>\quad 0.05$ at $\alpha=5 \%$

2. Ha is acceptable if the value of F count $>$ The value of F table or sig $<0.05$ at $\alpha=5 \%$

3. $\mathrm{F}_{\text {table }}$ can be viewed at $=0.05 \alpha$

Degree of Pemtell $=\mathrm{k}-1=4-1=3$ degrees denominator $=\mathrm{n}-\mathrm{k}=120-3=117 . \mathrm{F}_{\text {table }}=$ 2.68

Table 3. Simultaneous test (ANOVA $\left.{ }^{\mathrm{b}}\right)$.

\begin{tabular}{|c|c|c|c|c|c|}
\hline Model & Sum of Squares & $\mathrm{df}$ & Mean Square & $\mathrm{F}$ & Reserves the. \\
\hline Regression & 167.149 & 3 & 55.716 & 30.898 & $.000^{\mathrm{a}}$ \\
\hline Residual & 209.176 & 116 & 1.803 & & \\
\hline Total & 376.325 & 119 & & & \\
\hline
\end{tabular}

Source: Data Processing results (2019)

Based on Table 3, it can be seen the influence of each variable can simultaneously be seen that the value of Fcount $(30.898)>$ Ftabel $(2.68)$ or sig of $(0.000)<(0.05)$. Attributed to the existing theory, it shows that the free variables consisting of motivational variables (X1), Destination image variables (X2), and Contentment (X3) simultaneously have positive and significant effect on the bonded variable that is loyalty Travellers (Y).

\section{c. Test Determinations $\left(\mathbf{R}^{2}\right)$}

The calculation of the Coefisien determination to determine how much motivation, destination image, and satisfaction towards travellers loyalty. 
Table 4. Test Determinations $\left(\mathrm{R}^{2}\right) \mathrm{X} 1, \mathrm{X} 2, \mathrm{X} 3$ à $\mathrm{Y}$

\section{Model Summary ${ }^{\mathrm{b}}$}

\begin{tabular}{|l|l|l|l|l|}
\hline Model & $\mathrm{R}$ & $\begin{array}{l}\mathrm{R} \\
\text { Square }\end{array}$ & $\begin{array}{l}\text { Adjusted } \\
\mathrm{R} \text { Square }\end{array}$ & $\begin{array}{l}\text { Std. Error of the } \\
\text { Estimate }\end{array}$ \\
\hline 1 & $\mathbf{. 6 6 6}^{\mathrm{a}}$ & $\mathbf{. 4 4 4}$ & .430 & 1.34285 \\
\hline
\end{tabular}

Predictors: (Constant), Satisfaction, Motivation, Destination Image Source: Data Processing results (2019)

According to the Table 4, it can be seen that $R$ value is $0.666(66.6 \%)$, where the value of this correlation coefficient indicates that the relationship between motivation, destination image, and satisfaction towards tourist loyalty is strong. The value of $R$ Square or the value of the coefficient of determination above shows that the tourist loyalty variable $44.4 \%$ can be explained by the motivation variable, destination image, and satisfaction, while the remainder is $55.6 \%$ Influenced by other variables not contained in this study.

\section{Conclusion}

Based on the results of the research, data processing and analysis and discussion have been done as follows:

1. Based on the results that of the three free variables are motivation, destination image, and satisfaction is seen that only Motivation variables that do not have a significant influence, while other variables have a significant effect on the loyalty of tourists visiting the tourist areas of North Sumatera province. Associated with existing theories, simultaneous results indicates that the free variables consisting of motivational variables (X1), Destination image variables (X2), and Contentment (X3) simultaneously have a positive and significant effect on the bound variable i.e. Travellers loyalty (Y).

2. Based on the research that the majority of tourism visit North Sumatera province is dominated by women with the highest percentage whose activity is a student in terms of age between 17 to 25 years.

3. Based on the research that the tourism site in the province of North Sumatera in this case Lake Toba, Bukit Lawang, and Berastagi is the mainstay sector of tourism that is dominant in the visit by tourists.

4. Based on the results of the study that the level of visit to North Sumatera province tourism is categorized low. This is why travellers are difficult to decide on loyalty decisions for tourist sites.

\section{References}

Amin, M. A. S., Priansah, P. 2019. Marketing Communication Strategy to Improve Tourism Potential. Budapest International Research and Critics Institute-Journal (BIRCIJournal) (2): 160-166.Aritonang Lerbin R. 2005. Kepuasan Pelanggan. Jakarta: PT Gramedia Pustaka Utama.

Baker, D. A., \& Crompton, J. L. 2000. Quality, satisfaction, and behaviour intentions. Annals of Tourism Research, 27(3) 785-804

Baloglu, S., \& McCleary, K.W., (1999). A model of destination image formation Annals of tourism research, 26(4), 868-897 
Baloglu, S. (2001). Image Variations of Turkey by Familiarity Index: Informational and Experiential Dimensions. Tourism Management, 22, 127 - 133.

Badan Pusat Statistik .2018. Jumlah Kedatangan Wisatawan Mancanegara.

El-Sayed, S. S. M., Kader, R. R. A. and Yamin, A. A. Desert Environment Effect on the Deterioration of Ancient Building Materials in Archaeological Buildings (El-Bagawat Tombs, El -Kharga Oasis as an Example). Britain International of Exact Sciences (BIoEx) Journal (2): 476-485.

Heath, E. and G. Wall. (1992). Marketing Tourism Destinations, A Strategic Marketing Planning Approach. New York: John Wiley and Sons, Inc

Hsu, C.H., Cai, L.A., \& Li, M., (2009). Expectation, motivation, and attitude: A tourist behavioral model. Journal of Travel Research, 49(3)

Jeng, J., \& Fesenmaier, D. R. (2002). Conceptualizing the travel decision-making hierarchy: A review of recent developments. Tourism Analysis, 7(1), 15-32.

Mill, Robert Christie, (2000),"Tourism, the International Business". terjemahan Tri Budi Satrio, Penerbit Raja Grafindo. Jakarta.

Nguyen, Thao T, (2016) Medical Tourism: Studying the Impact of Motivational Factors, Destination Image On Perceived Quality And Overall Satisfaction Using Sem Analysis, Thesis, California State Polytechnic University, Pomona

Nurlina. 2020. Tourism Development in Langsa, Indonesia: An Overview of Tourist Attractions and Accommodation. Budapest International Research and Critics InstituteJournal (BIRCI-Journal) (3): 923-931.

Parasuraman, A.; Zeithaml, V.; dan Berry, L.L. (1988). "Servqual: A Multiple-Item Scalefor Measuring Consumer Perceptions of Service Quality". Journal of Retailing, Vol. 64Issue 1, pp. 12-40.

Parasuraman, A.; Zeithaml, V.; dan Berry, L.L. (1990). Delivering Quality Service. The FreePress, New York.

Sirakaya, E., \& Woodside, A. G. (2005). Building and testing theories of decision making by travellers. Tourism management, 26 (6), 815-832.

Septian Deny. 2017. Jumlah Wisatawan Dunia Diprediksi Capai 1,8 Juta Miliar pada 2030. www.Liputan 6.com

Sugiyono. (2012). Metode Penelitian Bisnis. Bandung: Alfabeta

Supranto, J. (1997). Pengukuran Tingkat Kepuasan Pelanggan untuk Menaikkan PangsaPasar. Jakarta: Rineka Cipta.

Supramono, dan Haryanto. 2003. Desain Proposal Penelitian: Studi Pemasaran. Yogyakarta: Andi.

Tjiptono, Fandy. (1998). Manajemen Jasa. Yogyakarta: Andi Offset.

Tjiptono, Fandy. (2008). Prinsip-prinsip Total Quality Service. Yogyakarta: Andi Offset.

Wahyudi, J., Silaban, G. and Aulia, D. 2020. The Relationship between Motivation Factors and Unsafe Action on Passenger Ship Crews in Tanjung Pinang. Britain International of Exact Sciences (BIoEx) Journal (2): 390-404.

Yoeti, Oka. (2008). Pemasaran Pariwisata. Bandung: Angkasa.

http://www.bps.go.id/pressrelease/2018/02/01/1468/jumlah-kunjungan-wisman-ke-indonesiadesember-2017-mencapai-1-15-juta-kunjungan--html, Access on 11 Juli 2018, 16:25

http://www.liputan6.com/bisnis/read/2932632/jumlah-wisatawan-dunia-diprediksi-capai-18juta-milyar-pada-2030, Access on11 July 2018, 16:28 